February 2000 • NREL/CP-500-26713

\title{
Investigation of Self-Excited Induction Generators for Wind Turbine Applications
}

E. Muljadi and C.P. Butterfield National Renewable Energy Laboratory Golden, Colorado

J. Sallan and M. Sanz University of Zaragoza

Zaragoza, Spain

Presented at the 1999 IEEE Industry Applications Society Annual Meeting

Phoenix, Arizona

October 3-7, 1999

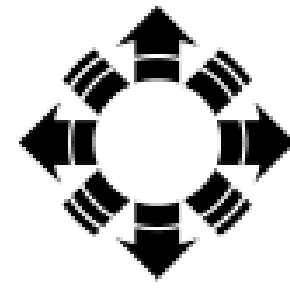

\section{NPEI}

National Renewable Energy Laboratory

1617 Cole Boulevard

Golden, Colorado 80401-3393

NREL is a U.S. Department of Energy Laboratory

Operated by Midwest Research Institute $\bullet$ Battelle $\bullet$ Bechtel

Contract No. DE-AC36-99-G010337 


\section{NOTICE}

The submitted manuscript has been offered by an employee of the Midwest Research Institute (MRI), a contractor of the US Government under Contract No. DE-AC36-99G010337. Accordingly, the US Government and MRI retain a nonexclusive royalty-free license to publish or reproduce the published form of this contribution, or allow others to do so, for US Government purposes.

This report was prepared as an account of work sponsored by an agency of the United States government. Neither the United States government nor any agency thereof, nor any of their employees, makes any warranty, express or implied, or assumes any legal liability or responsibility for the accuracy, completeness, or usefulness of any information, apparatus, product, or process disclosed, or represents that its use would not infringe privately owned rights. Reference herein to any specific commercial product, process, or service by trade name, trademark, manufacturer, or otherwise does not necessarily constitute or imply its endorsement, recommendation, or favoring by the United States government or any agency thereof. The views and opinions of authors expressed herein do not necessarily state or reflect those of the United States government or any agency thereof.

Available electronically at http://www.doe.gov/bridge

Available for a processing fee to U.S. Department of Energy and its contractors, in paper, from:

U.S. Department of Energy

Office of Scientific and Technical Information

P.O. Box 62

Oak Ridge, TN 37831-0062

phone: 865.576 .8401

fax: 865.576.5728

email: reports@adonis.osti.gov

Available for sale to the public, in paper, from:

U.S. Department of Commerce

National Technical Information Service

5285 Port Royal Road

Springfield, VA 22161

phone: 800.553 .6847

fax: 703.605.6900

email: orders@ntis.fedworld.gov

online ordering: http://www.ntis.gov/ordering.htm

Printed on paper containing at least $50 \%$ wastepaper, including $20 \%$ postconsumer waste 


\title{
Investigation of Self-Excited Induction Generators for Wind Turbine Applications
}

\author{
Eduard Muljadi \# Jesus Sallan* Mariano Sanz* Charles P. Butterfield ${ }^{*}$ \\ \# National Renewable Energy Laboratory \\ 1617 Cole Boulevard \\ Golden, CO 80401 \\ Tel. (303) 384-6900, Fax (303) 384-6999 \\ Eduard_muljadi@nrel.gov, http://www.nrel.gov/wind \\ * University of Zaragoza \\ Electrical Engineering Department \\ Maria de Luna 3, 50015 Zaragoza, Spain \\ Phone/Fax: 34976761925 / 762226 \\ e-mail: jsallan@posta.unizar.es
}

\begin{abstract}
The use of squirrel-cage induction machines in wind generation is widely accepted as a generator of choice. The squirrel-cage induction machine is simple, reliable, cheap, lightweight, and requires very little maintenance. Generally, the induction generator is connected to the utility at constant frequency. With a constant frequency operation, the induction generator operates at practically constant speed (small range of slip). The wind turbine operates in optimum efficiency only within a small range of wind speed variation. The variable-speed operation allows an increase in energy captured and reduces both the torque peaks in the drive train and the power fluctuations sent to the utility.

In variable-speed operation, an induction generator needs an interface to convert the variable frequency output of the generator to the fixed frequency at the utility. This interface can be simplified by using a self-excited generator because a simple diode bridge is required to perform the ac/dc conversion. The subsequent dc/ac conversion can be performed using different techniques. The use of a thyristor bridge is readily available for large power conversion and has a lower cost and higher reliability. The firing angle of the inverter bridge can be controlled to track the optimum power curve of the wind turbine. With only diodes and thyristors used in power conversion, the system can be scaled up to a very high voltage and high power applications.

This paper analyzes the operation of such a system applied to a 1/3-hp self-excited induction generator. It includes the simulations and tests performed for the different excitation configurations.
\end{abstract}

\section{INDEX TERMS}

Wind energy, variable-speed generation systems, renewable energy, self excitation.

\section{INTRODUCTION}

Many types of generator concepts have been used and proposed to convert wind power into electricity. The size of the wind turbines has increased during the past ten years, and the cost of energy generated by wind turbine has decreased. The challenge is to build larger wind turbines and to produce cheaper electricity. Thus, there is a need to find a way to convert wind energy into electrical energy from wind turbines that can be scaled up in power without extremely high cost penalties.

In this paper, a combination of series [1] and parallel [2] capacitors are used to excite the induction generator while operating at variable speeds. In the self-excited mode, the induction generator is excited with three-phase ac capacitors. The frequency, the slip, the air gap voltage and the operating range of the system are affected by the characteristics of the induction generators and the choice capacitor sizes. The operating slip in a self-excited mode is generally small and the variation of the frequency depends on the operating speed range. The system we tested has the following components: - a 1/3-hp dc machine to represent the wind turbine - a three-phase, 1/3-hp, induction generator driven by the dc machine

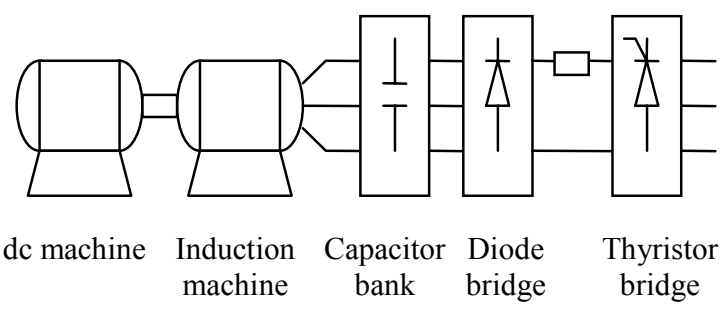

Figure 1. Scheme of the system 
- various sets of capacitors to provide reactive power to the induction generator

- a three-phase diode bridge to rectify the current provided by the generator

- a dc reactor to smooth the dc current and to limit the current peaks on the dc bus

- a three-phase thyristor bridge to convert the power from the dc bus to the utility.

The organization of this paper will be presented as follows: Section II of this paper is devoted to wind turbine operation and the proposed system. Section III is devoted to the concept of self excitation of an induction generator. In Section IV, we present series compensation and in Section V, the combination of series and parallel compensation is presented. The last section summarizes the results.

\section{WIND TURBINE}

In wind parks, many wind turbines are equipped with fixed frequency induction generators. Thus the power generated is not optimized for all wind conditions. To operate a wind turbine at its optimum at different wind speeds, the wind turbine should be operated at its maximum power coefficient $\left(\mathrm{C}_{\mathrm{p} \text {-optimum }}=0.3-0.5\right)$. To operate around its maximum power coefficient, the wind turbine should be operated at a constant tip-speed ratio, which is proportional to ratio of the rotor speed to the wind speed. As the wind speed increases, the rotor speed should follow the variation of the wind speed. In general, the load to the wind turbine is regulated as a cube function of the rotor rpm to operate the wind turbine at the optimum efficiency. The aerodynamic power generated by wind turbine can be written as:

$$
\mathrm{P}=0.5 \rho \mathrm{AC}_{\mathrm{p}} \mathrm{V}^{3}
$$

Where the aerodynamic power is expressed as a function of the specific density $(\rho)$ of the air, the swept area of the blades (A) and the wind speed (V). To operate the wind turbine at its optimum efficiency $\left(\mathrm{C}_{\mathrm{p} \text {-optimum }}\right)$, the rotor speed must be varied in the same proportion as the wind-speed variation. If we can track the wind speed precisely, the power can also be expressed in terms of the rotor speed.

$$
\mathrm{P}=\mathrm{K}_{\mathrm{p}} \mathrm{rpm}^{3}
$$

The power described by equation [2] will be called $\mathrm{P}_{\text {ideal }}$. This is the power to be generated by the generator at different rotor rpm. One way to convert a wind turbine from fixedspeed operation to variable-speed operation is to modify the system from a utility-connected induction generator to a selfexcited operation. Ideally, if the inertia of the wind turbine rotor is negligible, the rotor speed can follow the variation of the wind speed if the output power of the generator is controlled to produce the power-speed characteristic described in equation 2. Thus the wind turbine will always operate at $\mathrm{C}_{\mathrm{p} \text {-optimum. }}$ In reality, the wind turbine rotor has a significantly large inertia due to the blade inertia and other components. The wind turbine operation can only in the vicinity of $\mathrm{C}_{\mathrm{p} \text {-optimum. }}$ However, compared to fixed-speed operation, the energy captured in variable-speed operation is significantly higher.

With variable-speed operation and sufficiently large rotor inertia, there is a buffer between the energy source (wind) and energy sink (utility). Allowing the rotor speed to vary has the advantage of using the kinetic energy to be transferred in and out of the rotor inertia. Thus, the aerodynamic power, that fluctuates with the wind input, is filtered by the inertia before it is transmitted to the utility grid. This concept is very similar to the use of de filter capacitor at the dc bus of a dc-dc converter. The dc capacitor filters the voltage ripple so that the voltage output presented to the load will be a smooth output voltage. It is expected that the turbulent content in wind input will not be transmitted directly to the mechanical drives (gearbox) of the wind turbines thus the mechanical stress and fatigues on mechanical components can be relieved. Thus, the lifetime of the mechanical drives and other components of the wind turbine can be extended by variable-speed operation.

\section{SELF-EXCITED INDUCTION GENERATOR}

The induction machine is modeled using the steady-state equivalent circuit shown in Figure 2. Detail derivation of equations for self-excited induction generator can be found in many papers [3-4]. The frequency dependent reactance is scaled by per unit frequency. Per unit frequency $\left(f_{p u}\right)$ is the ratio of operating frequency to the rated frequency $(60 \mathrm{~Hz})$. The stable operation of the system can be sustained at any moment when the balance of real power and reactive power can be maintained. The balance of real power is established mainly between the power produced in the rotor and the power consumed from the stator winding through the power converter. The balanced of reactive power is established between the ac capacitors and the air-gap flux condition at any operating condition.

From the equivalent circuit shown in Figure 2a, the equivalent circuit can be represented in terms of its admittance. The admittance of the stator branch consists of the stator resistance, stator leakage inductance, the stator load resistance representing the power drawn by the diode bridge at the stator, and the excitation capacitor. Given the load resistance, the capacitor size, the stator leakage inductance and stator resistance, the stator admittance can be found. The stator admittance can be represented as: 

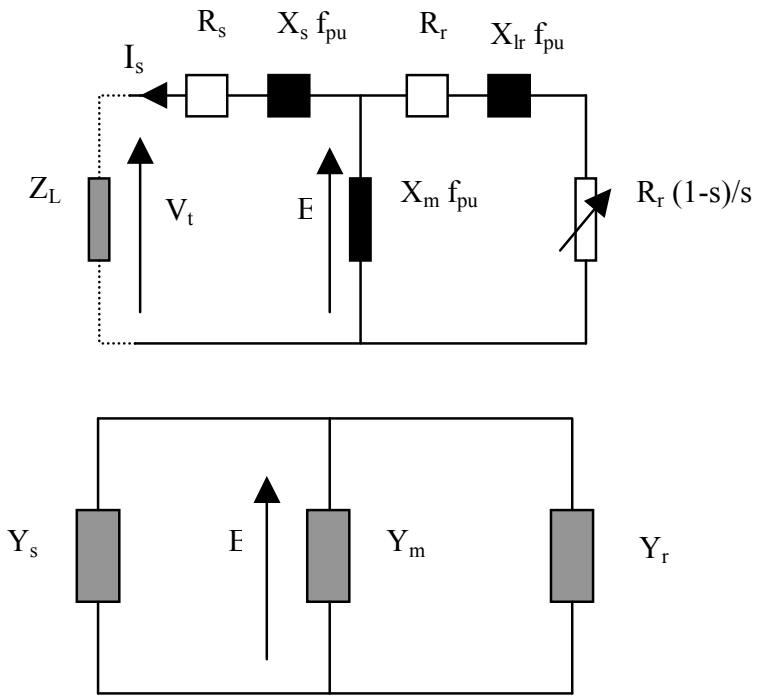

Figure 2. Equivalent circuit of the induction machine

$Y_{\mathrm{s}}=\operatorname{Re}\left(\mathrm{Y}_{\mathrm{s}}\right)+\mathrm{j} \operatorname{Im}\left(\mathrm{Y}_{\mathrm{s}}\right)$

The rotor branch can be represented as:

$Y_{r}=\frac{\frac{R_{r}}{s}}{\left(\frac{R_{r}}{s}\right)^{2}+\left(X_{l r} f_{p u}\right)^{2}}-j \frac{X_{l r} f_{p u}}{\left(\frac{R_{r}}{s}\right)^{2}+\left(X_{l r} f_{p u}\right)^{2}}$

The magnetizing branch can be represented as:

$Y_{m}=-j \frac{1}{X_{m}}$

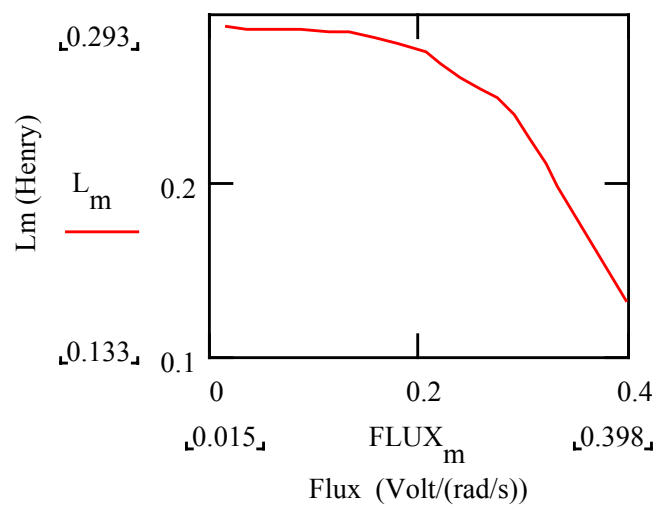

Figure 3. Magnetizing curve of the induction machine
The balance of real power can be found by equating the real part of the stator branch and the real part of the rotor branch:

$$
\operatorname{Re}\left(\mathrm{Y}_{\mathrm{s}}\right)+\frac{\frac{\mathrm{R}_{\mathrm{r}}}{\mathrm{s}}}{\left(\frac{\mathrm{R}_{\mathrm{r}}}{\mathrm{s}}\right)^{2}+\left(\mathrm{X}_{\mathrm{lr}} \mathrm{f}_{\mathrm{pu}}\right)^{2}}=0
$$

The slip can be solved from Equation 6. The next thing to solve is the airgap voltage at this operating point. The relationship of the imaginary part of the rotor branch, the stator branch, and the magnetizing branch is given in Equation 7. It can be used to solve $X_{\mathrm{m}}$. From $X_{\mathrm{m}}$ and the operating frequency, the airgap voltage $\left(\mathrm{E}_{60 \mathrm{~Hz}} \mathrm{f}_{\mathrm{pu}}\right)$, the magnetizing curve, and the operating frequency, the airgap flux and airgap voltage can be found.

$$
\operatorname{Im}\left(Y_{s}\right)+\frac{X_{l r} f_{p u}}{\left(\frac{R_{r}}{s}\right)^{2}+\left(X_{l r} f_{p u}\right)^{2}}+\frac{1}{X_{m} f_{p u}}=0
$$

The relationship between the magnetizing inductance $\mathrm{L}_{\mathrm{m}}$ as a function of flux linkage $(E / \omega)$ is given in Figure 3 . It is shown how the value of $\mathrm{L}_{\mathrm{m}}$ decreases as the induction generator saturates. From the $\mathrm{L}_{\mathrm{m}}$, the airgap voltage can be found. The terminal voltage, the stator and rotor current, the airgap voltage, and input power can be computed.

\section{PARALLEL COMPENSATION}

In this section, the parallel compensation is investigated. The three-phase ac capacitors are connected in parallel with the load at the terminal of the induction generator. The load is a power converter consisting of the diode bridge and the thyristor bridge. To the generator, the diode bridge presents a unity power factor load. Although the current waveform at the input to the diode bridge is distorted, the presence of the

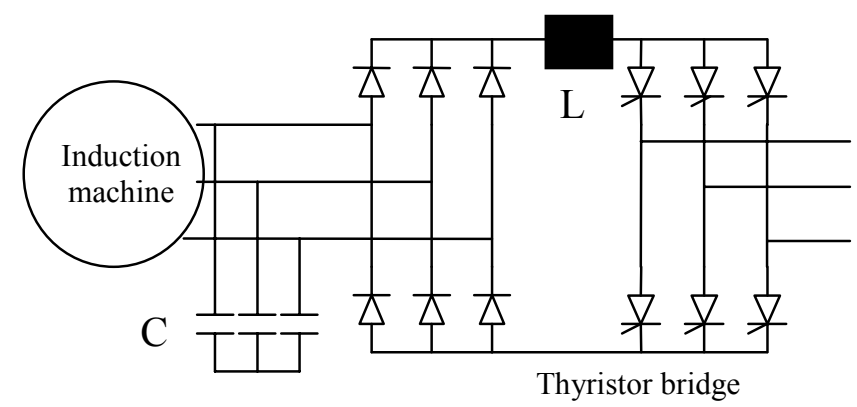

Figure 4. Parallel compensation 


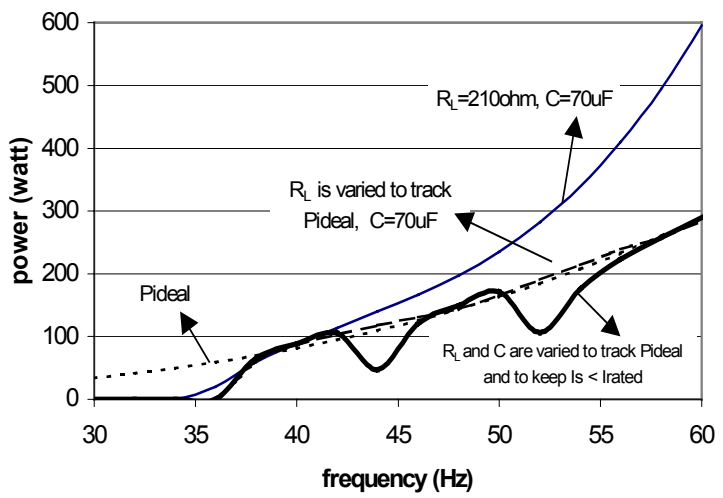

Figure 5. Power versus frequency of a parallel excited induction generator

ac capacitors helps to smooth out the current shape. The power output of the generator can be adjusted by controlling the firing angle of the phase-controlled inverter at the utility side. Thus, the utility is seen by the generator as an adjustable energy sink. For steady-state analysis and considering only the fundamental component of the current waveform, the load can be replaced as an adjustable resistive load $\mathrm{R}_{\mathrm{L}}$

Figure 4 shows the physical diagram of parallel compensation. The load and the capacitor compensation can be represented as $Z_{\text {Load. }}$. The admittance of the stator and the load can be expressed as:

$\bar{Y}_{\mathrm{s}}=\left(\overline{\mathrm{Z}}_{\mathrm{Load}}+\overline{\mathrm{Z}}_{\mathrm{s}}\right)^{-1}$

where $Z_{\text {load }}$ and $Z_{s}$ are given as:

$$
\begin{aligned}
& \bar{Z}_{\text {Load }}=\frac{1}{\frac{1}{R_{L}}+j \omega C} \\
& \bar{Z}_{s}=R_{s}+j X_{l s} f_{p u}
\end{aligned}
$$

Using the equations above and the saturation curve of $\mathrm{X}_{\mathrm{m}}$, the operating condition of the induction generator is examined. The adjustable converter load is represented by resistive load. Three cases are examined. The first one is a constant resistive load $\left(\mathrm{R}_{\mathrm{L}}=210 \mathrm{ohm}\right)$ in parallel with a constant capacitive load $(\mathrm{C}=70 \mu \mathrm{F})$. The frequency is varied and the operating points are computed. The second one is the same as the first one except the resistance of the load is varied so that the output power tracks the ideal power to optimize the wind turbine operation. The third one is to change the capacitor sizes in three different values while changing the resistive load to optimize the wind turbine operation. The capacitor size is started at $70 \mu \mathrm{F}$ and the resistive load is changed as the frequency is increased. When

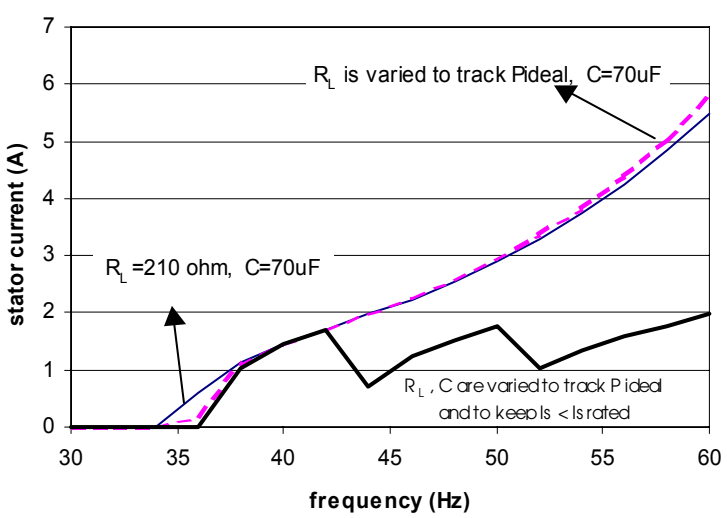

Figure 6. Stator current versus frequency of a parallel excited induction generator

the stator current reaches its rated value, another capacitor value is used and the resistance is varied again and so on.

We show in Figure 5 that to track the $P_{\text {ideal }}$, the load must be represented as a variable resistance. Using a constant resistance load, the generated power increases above the rated power of the generator as the frequency is increased. With a variable-resistance load, it is possible to follow the ideal power for a wide range of frequency variation as shown by the dash-dot line. Similarly, with three different capacitors, it is possible to follow ideal power for a wide range of operating frequencies.

In Figure 6, the stator currents for three different cases are shown. For constant resistance load, the power cannot follow the Pideal, and the stator current goes above the rated current. By changing the values of the capacitor for different ranges of operating frequency, it is possible to keep the stator current below its rated value. It is shown from Figure 6 that as the stator current goes above its rated, a new capacitor value is applied to the system. Note that there are discontinuities of the operating points when changing the capacitance values.

In Figure 7, the value of magnetizing inductance $L_{m}$ as the frequency changes are shown for three different cases. The

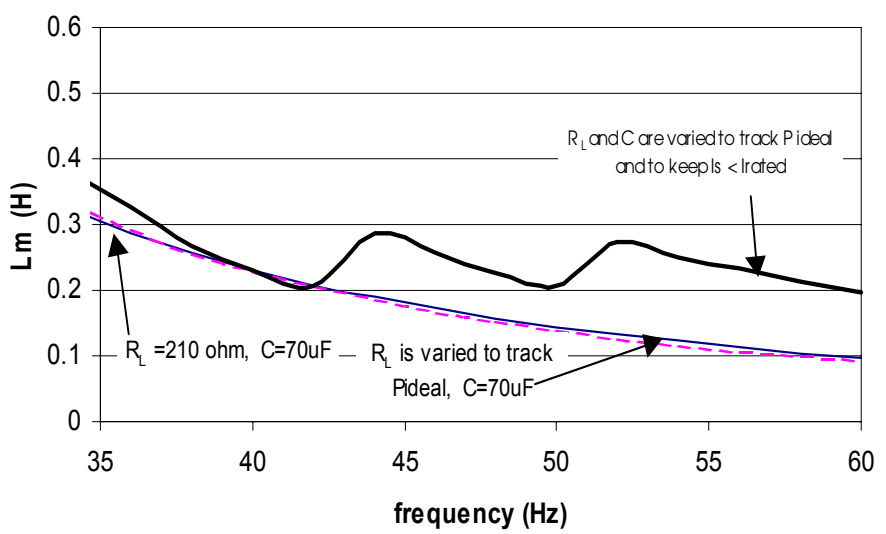

Figure 7. Magnetizing inductance $\mathrm{L}_{\mathrm{m}}$ for a parallel excited induction generator 
values of $\mathrm{L}_{\mathrm{m}}$ indicate the level of saturation at any operating condition. The first two cases that use a single value of capacitor show very high saturation level at higher operating frequencies, while using three different capacitor sizes enables the system to operate at an average or almost constant level of saturation.

\section{SERIES-PARALLEL COMPENSATION}

The system configuration for series-parallel compensation is shown in Figure 8. In this configuration, both the series capacitor $\mathrm{C}_{2}$ and the parallel capacitor $\mathrm{C}$ affect the level of excitation. The series capacitance $\mathrm{C}_{2}$ helps to increase the level of excitation and counteracts the voltage drop across the stator resistance and stator leakage inductance.

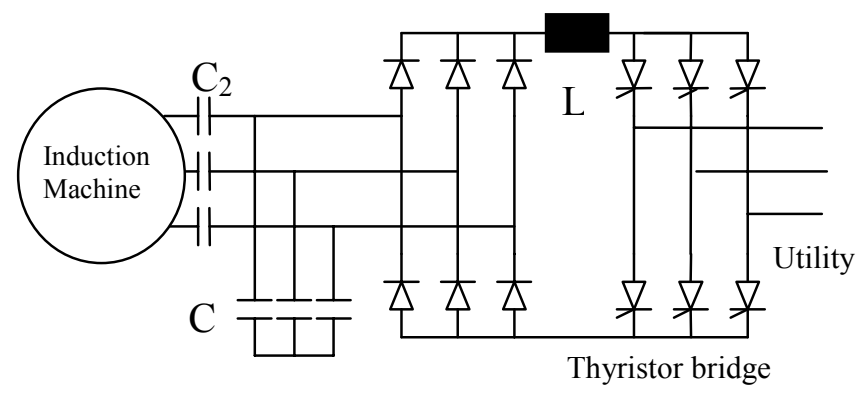

Figure 8. Series-parallel excitation of the induction machine

In this case, the load impedance is:

$$
\bar{Z}_{\text {Load }}=\frac{1}{\frac{1}{R_{L}}+j \omega C}+\frac{1}{j \omega C_{2}} .
$$

In Equation 5, the terminal of the induction generator is connected to the series capacitor and the parallel capacitor is connected in parallel with the diode bridge. The parallel capacitor compensates the main reactive power needed by the

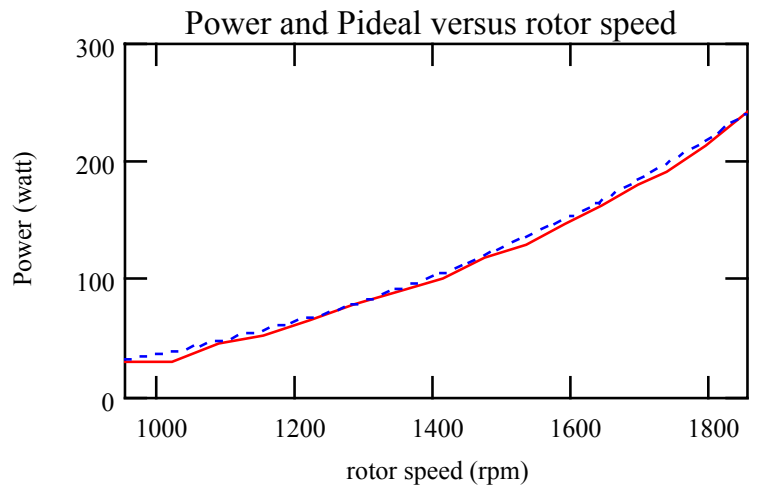

Figure 9. Power (in watts) versus rotor speed for series-parallel excited generator

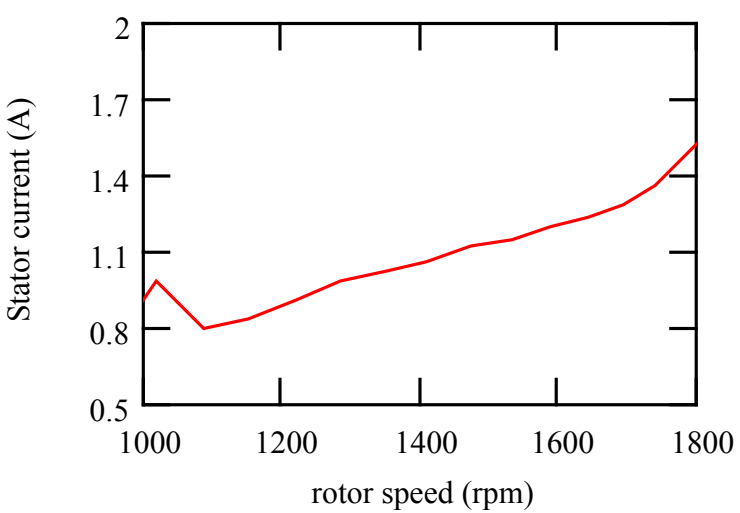

Figure 10. Stator current versus rpm for a seriesparallel excitation induction machine

induction generator to counteract the main magnetizing winding $L_{m}$, which size varies with the level of saturation.

A steady-state analysis is performed to understand the behavior of the system. The compensation chosen is the parallel capacitor $\mathrm{C}=40 \mu \mathrm{F}$ and the series compensation capacitor $\mathrm{C}_{2}=150 \mu \mathrm{F}$ ). As in the previous section, the power converter is simulated by an adjustable resistive load $R_{L}$. Apparently, a normal operating condition can be achieved by using this pair of capacitance values. The ideal power can be achieved and the stator current stays below the rated value in the entire range of operation.

In Figure 9, the output power of the generator (solid line) and $\mathrm{P}_{\text {ideal }}$ (dashed line) are shown. The system can track the ideal power for a wide range of operating frequencies.

In Figure 10, the stator current as a function of the frequency is shown. Note that the stator current stays within the rated value in the entire range of operation.

The level of excitation can be shown by the variation of inductance $\mathrm{L}_{\mathrm{m}}$ as the frequency is varied. This variation is shown in Figure 11. Comparing Figure 11 and Figure 7, it is clear that the series compensation can satisfactorily maintain the level of saturation. It is shown that in the lower frequency, the saturation level is very low and the stator current required to track the ideal power is also low. Thus both the iron losses and the copper losses are low in the low frequency, which indicates that the operation of the system is efficient even in the lower frequency region.

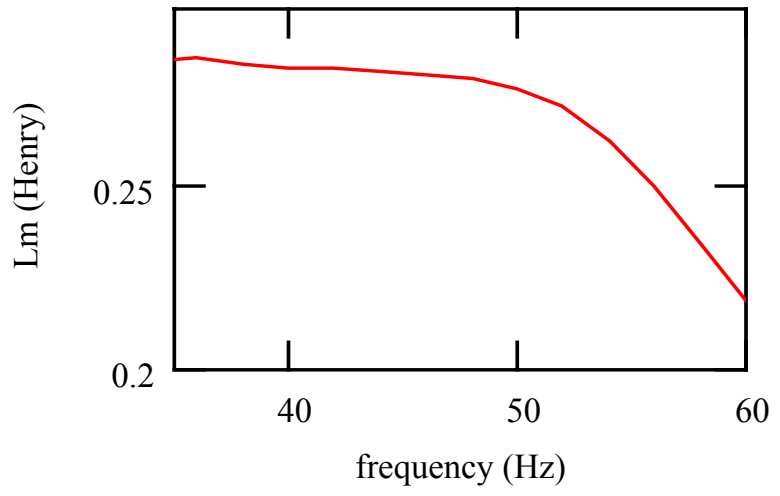

Figure 11. Magnetizing inductance (in $\mathrm{H}$ ) versus frequency for series-parallel excited generator 


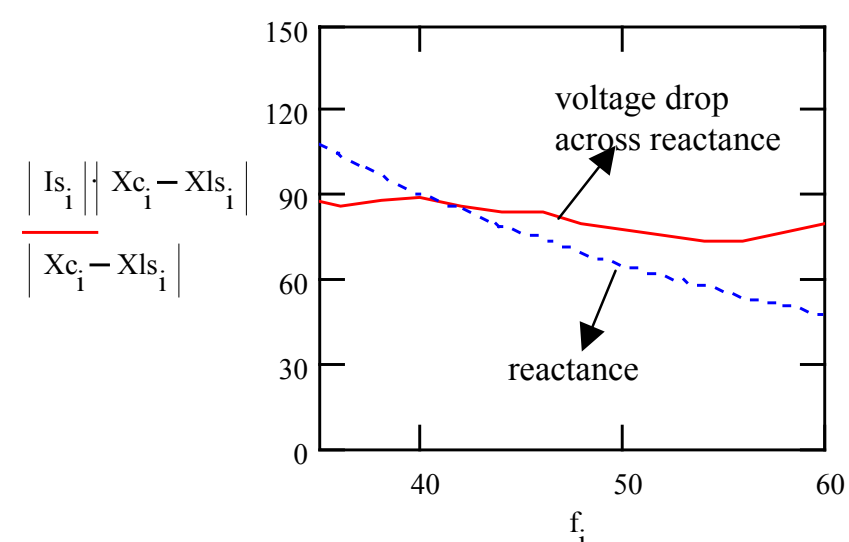

Figure 12. Voltage drop across reactance and the reactance (Xc-Xls) versus frequency

It should be pointed out that the series-parallel compensation operates smoothly because there is no need to change the capacitor size. The capacitor pair chosen can be used for the entire range of operation. The series capacitor should be able to carry the rated current as the induction generator, while the parallel capacitor should be rated to withstand the output voltage at the terminal of the power converter. Both the series and parallel capacitors are ac capacitors.

It is interesting to observe the series capacitor compensates for the voltage-drop across the stator leakage inductance. Figure 12 shows the total reactance (Xc-Xls) and the voltage drop across it. In this circuit, the series capacitive-reactance is more dominant than the stator leakage reactance, the total reactance drops as the frequency increases. However, as the frequency increases, the demand for the stator current also increases. Thus the voltage drop across the total reactance (Xc-Xls) is almost constant for the entire range of operation.

In Figure 13, the actual data from experimental results collected in the laboratory is drawn on the same figure as the ideal power $\mathrm{P}_{\text {ideal }}$. The experimental data fits the ideal curve down to a speed of $900 \mathrm{rpm}$, one-half of the rated speed. The test results shown verify that for the steady-state calculation presented in this section. Note that in optimum operation of a wind turbine, the power is a cube function of the rotor speed.

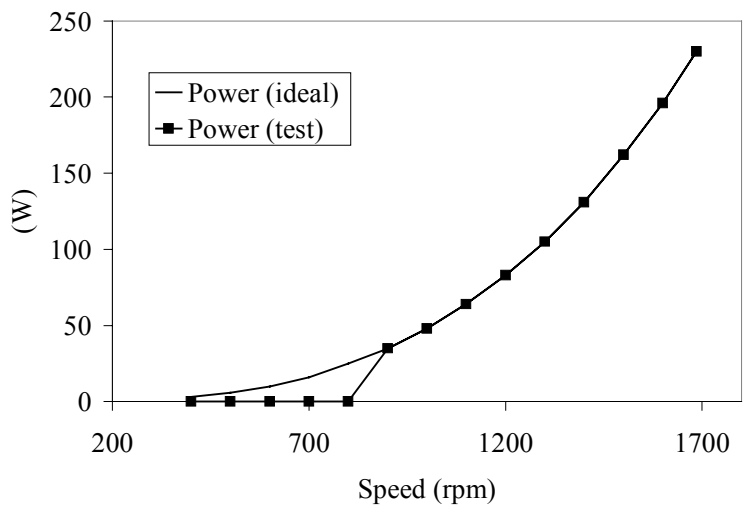

Figure 13. Power versus rotor speed from experimental data
Thus, if the upper limit is set to $\mathrm{P}_{\text {rated }}$, the lower limit that is $50 \%$ of the rated speed will generate about $1 / 8(12.5 \%)$ of the rated power.

\section{A. Generator voltage and current waveforms}

Figure 14a shows the phase voltage and line current in the generator when working in rated conditions. The voltage waveform is affected by the current distortion. Figure $14 \mathrm{~b}$, shows the frequency spectrum of the current waveform. The current waveform contains minimal harmonic components.

The parallel capacitors at the output terminal across the diode bridge filters the harmonics current entering the generator. It is expected that the harmonic losses due to current harmonics is reduced significantly. The torque pulsation which is normally associated with current harmonics is expected to be very small as well. The effect of torque pulsation on the speed fluctuation is further reduced by the fact that the blade inertia is very large compare to normal load. Thus the rotor speed fluctuation due to harmonics is barely be noticeable.

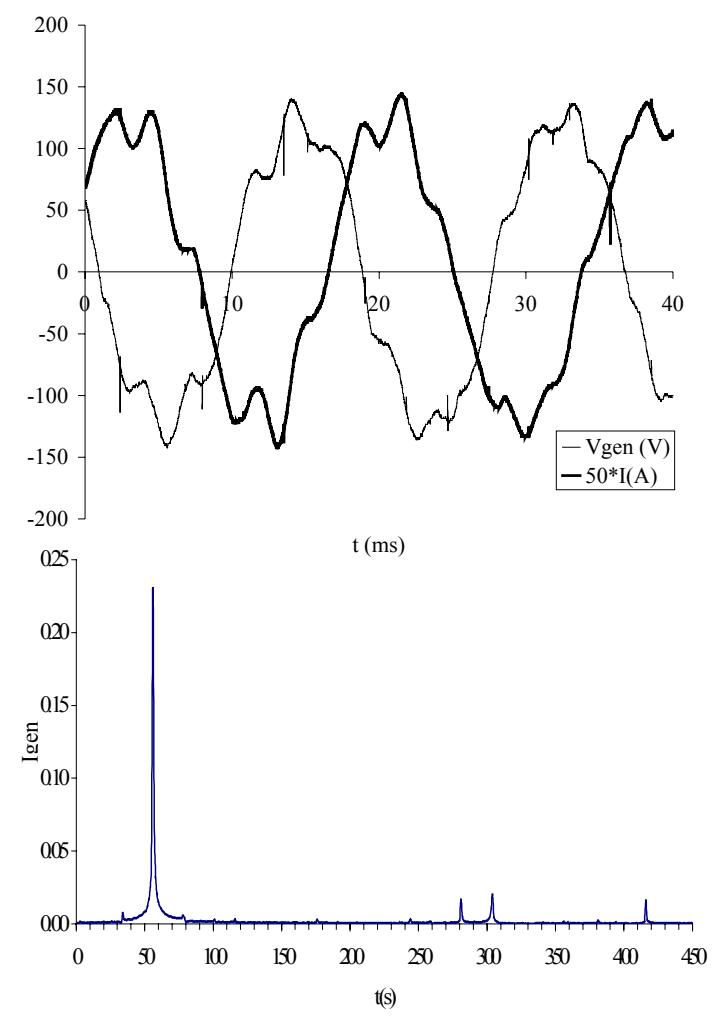

Figure 14. Voltage and current waveform at the generator terminal output

\section{B. Utility voltage and current waveforms}

Figure 15 shows the utility voltage and current. The latter has the typical shape of a thyristor inverter current, with high ripple. Its frequency spectrum shows the high value of the fifth and seventh harmonics. With proper filtering at the 


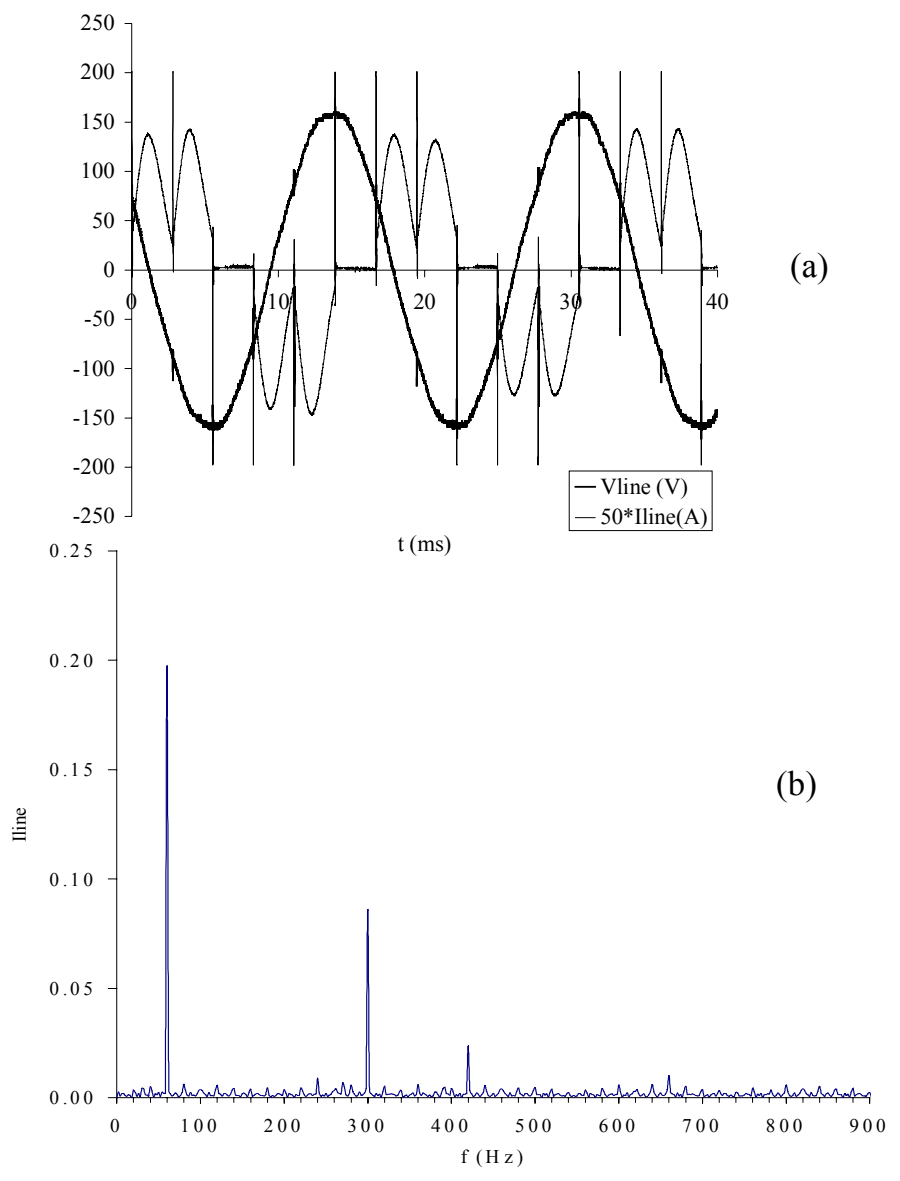

Figure 15 . Utility phase voltage and line current.

a) Current and voltage waveform

b) Frequency spectrum of the utility line current

point of common coupling the current harmonics can be reduced to an acceptable level.

\section{Parameter Determination Test}

A no-load circuit test and lock rotor tests are performed. The parameters of the induction generator are computed from the test data, and the results are listed in Table 1.

Table 1. Induction Machine Data from the Tests

\begin{tabular}{|c|c|}
\hline \hline \multicolumn{2}{|c|}{ Induction Machine Data } \\
\hline Resistances & Reactances at $60 \mathrm{~Hz}$ \\
\hline $\mathrm{R}_{\mathrm{s}}=5.7 \Omega$ & $\mathrm{X}_{\mathrm{s}}=\mathrm{X}_{\mathrm{r}}=5.76 \Omega$ \\
\hline $\mathrm{R}_{\mathrm{r}}=4.35 \Omega$ & $\mathrm{X}_{\mathrm{m}, \text { nom }}=88.1 \Omega$ \\
\hline 4 pole & Rated power $=3 / 4 \mathrm{HP}$ \\
\hline Line Voltage $=230$ volts & Frequency $=60 \mathrm{~Hz}$ \\
\hline \hline
\end{tabular}

\section{CONCLUSIONS}

We investigated the proposed generator for application in wind power generation. In the first stage of implementation, a proof of concept of the generator was investigated. This paper demonstrates the technical viability of using a selfexcited induction generator in variable-speed wind generation. This greatly simplifies the power stages needed to connect to the utility compared with inverter-fed induction generators.

The series-parallel compensation system tracks the maximum power curve of the wind turbine over a wide range of speed, with a pair of capacitor values. The power stage of the power converter consists of diodes and thyristors, thus, this system can be scaled up to a higher voltage and higher power to process very high power in wind power generation.

Its main drawback is the non-sinusoidal output current generated at the grid. However, many schemes have been proposed to improve the power quality at the output of the phase-controlled inverter such as passive filter, active filter, or other topologies.

\section{ACKNOWLEDMENTS}

The authors wish to thank Jerry Bianchi for his assistance during the test set up of this generator.

We wish to acknowledge our management at National Renewable Energy Laboratory and the U.S. Department of Energy for encouraging us and approving the time and tools we needed for this project. DOE supported this work under contract number DE-AC36-98-GO10337.

\section{REFERENCES}

1. C.F. Wagner, "Self-Excitation of Induction Motors with Series Capacitors." AIEE Transactions, February 1941, Vol. 60, pp. 1241-1247.

2. E. Muljadi, B. Gregory, and D. Broad "Self-excited Induction Generator for Variable-Speed Wind Turbine Generation." Powersystems World'96 Conference, Las Vegas, Nevada. Alternative Energy Session, September 7-13, 1996, pp. 343-352.

3. T.F. Chan "Self-excited Induction Generators Driven by Regulated and Unregulated Turbines." IEEE Transactions on Energy Conversion, June 1996,Vol. 11, No. 2.

4. K.E. Hallenius, P Vas, J.E. Brown. "The Analysis of a Saturated Self-Excited Asynchronous Generator." IEEE Transactions on Energy Conversion, June 1991, Vol. 6, No. 2. 